\title{
DNA barcode identification of commercial fish sold in Mexican markets
}

\begin{tabular}{|r|l|}
\hline Journal: & Genome \\
\hline Manuscript ID & gen-2017-0222.R2 \\
\hline Manuscript Type: & Article \\
\hline Complete List of Authors: & $\begin{array}{l}\text { Sarmiento-Camacho, Stephanie; Benemerita Universidad Autonoma de } \\
\text { Puebla, Facultad de Ciencias Biológicas } \\
\text { Valdez-Moreno, Martha; El Colegio de la Frontera Sur, Ecología y } \\
\text { Sistemática Acuática }\end{array}$ \\
\hline $\begin{array}{r}\text { Is the invited manuscript for } \\
\text { consideration in a Special } \\
\text { Issue? : }\end{array}$ & N/A \\
\hline Keyword: & COI, shark, seafood, Mexico, threatened species \\
\hline &
\end{tabular}

SCHOLARONE $^{\text {m }}$

Manuscripts 


\section{DNA barcode identification of commercial fish sold}

2 in Mexican markets.

3 S. Sarmiento- Camacho ${ }^{1}$, M. Valdez-Moreno ${ }^{2}$

4

51 Facultad de Ciencias Biológicas, Benemérita Universidad Autónoma de Puebla,

6 Edificio 112-A, Blvd. Valsequillo y Av. San Claudio, Ciudad, Universitaria, Col.

7 Jardines de San Manuel, 72570, Puebla, Puebla, Mexico.

8

92 Necton Lab, Department of Aquatic Ecology and Systematics, El Colegio de la

10

11

12

13

14

15

16

17

18

19 


\section{Abstract}

The substitution of high-value fish species for those of lower value is common practice. Although numerous studies have addressed this issue, few have been conducted in Mexico. In this study, we sought to identify fresh fillets of fish, sharks, and rays using DNA barcodes. We analyzed material from "La Viga" in Mexico City, and other markets located on the Gulf and Caribbean coasts of Mexico. From 134 samples, we obtained sequences from 129, identified to nine orders, 28 families, 38 genera, and 44 species. The most common species were Seriola dumerili, Pangasianodon hypophthalmus, Carcharhinus falciformis, Carcharhinus brevipinna, and Hypanus americanus. P. hypophthalmus was most commonly used as a substitute for higher-value species. The substitution rate was $18 \%$ of the total. A review of the conservation status of the specimens identified against the IUNC list enabled us to establish that some species marketed in Mexico are threatened: Makaira nigricans, Lachnolaimus maximus, Hyporthodus flavolimbatus and Isurus oxyrinchus are classified as vulnerable; Lopholatilus chamaeleonticeps and Sphyrna lewini are endangered; and the status of Hyporthodus nigritus is critical. These results will demonstrate to the Mexican authorities that DNA barcoding is a reliable tool for species identification, even when morphological identification is difficult or impossible.

Keywords: COI, fish, sharks, Pangasius, seafood, conservation species, endangered species. 
42

43 Fisheries in Mexico have for a long time been reported to be operating at their

44 maximum level (FAO 1997). In spite of this, however, the fishing effort is still

45 increasing (CONAPESCA 2013). As a consequence, the catch per unit effort for

46 marine species of economic importance had fallen by $30 \%$ between the end of the

47 1980s and 2011, and in the coming years could fall by a further $50 \%$ (Rodríguez

48 Sánchez et al. 2011).

49 The scarcity of some species that are most appreciated by consumers has led to

50 an increase in their value, or they have unknowingly been replaced with lower-

51 priced products. This latter problem frequently occurs when the fish products have

52 been processed or frozen, because by this time it is generally impossible to

53 determine species identity by visual identification (Bartlett and Davidson 1992;

54 Mackie et al. 1999; Filonzi et al. 2010).

55 DNA barcoding has been widely used to detect this fraud since 2008 (Ogden

56 2008). To date, there have been more than 25 studies from different countries

57 dealing with this topic; for example, those undertaken in Brazil (Carvalho et al.

58 2015a), Canada (Hanner et al. 2011; Steinke et al. 2017), China (Shen et al. 2016),

59 France (Bénard-Capelle et al. 2015a), Italy (Cutarelli et al. 2014), and South Africa

60 (Cawthorn et al. 2015).

61 In all these studies, the application of barcoding in fresh and processed products

62 has facilitated the detection of substituted and mislabeled seafood, which has

63 different effects on the final consumers. These include economic losses due to 
potential commercial fraud (Filonzi et al. 2010; Ropicki et al. 2010; Huxley-Jones et al. 2012; Cutarelli et al. 2014; Forbes and Alexander 2015; Pappalardo and Ferrito 2015; Carvalho et al. 2015b; Galal-Khallaf et al. 2016; Xiong et al. 2016), public health repercussions due to ingestion of contaminated food (Chang et al. 2008;

Todd 2011; Raimann et al. 2014), trade promotion of invasive species (Pilger et al. 2008), uncontrolled impacts on fish species of threatened status (Stevens et al. 2000; Ardura et al. 2010, 2011), and damage to populations due to overfishing (Tokeshi et al. 2013). All of these studies have provided evidence to the necessary authorities that would enable the application of penalties against commercial establishments that have committed fraud.

The substitution and mislabeling of fresh or processed seafood are considered a global problem, and the prevalence of these practices has been increasing as there is currently no standard system for seafood labeling (Cawthorn et al. 2015). In the case of Mexico, since 1995, there has been legislation for labeling freshchilled and frozen fish products, which is set out in the following publication: (http://www.dof.gob.mx/nota detalle.php?codigo=4870248\&fecha=03/03/1995). This document contains regulations regarding the labeling of products. In the case refrigerated products, labels must include the following details: Lot Number; Day, Month, and Year of elaboration; the text "Keep refrigerated at maximum $4^{\circ} \mathrm{C}$; and Expiry Date, indicating day, month, and year. Similarly, for a frozen product, labels should include the following: Lot Number; Day, Month, and Year of elaboration; an indication of the food additives used, and the texts "Keep frozen at a maximum 
86 temperature of $-18^{\circ} \mathrm{C}$ " and "Once thawed it should not be refrozen." It is,

87 nevertheless, clear that this legislation is incomplete, and is lacking in details.

88 Against this background, we examined the potential of implementing barcoding

89

90

91

92

93

94

95

96

97

98

99

100

101

102

103

104

105 106

107

analysis for a wide range of seafood (bony fish, sharks, and rays) to confirm the identity of these products, with the aims of demonstrating the effectiveness of this method to the concerned Mexican authorities, raising the level of awareness among consumers, and promoting the introduction of precise product labeling.

\section{Materials and methods}

\section{Sample collection}

Fresh muscle samples of bony fish, sharks, and rays were collected from seven different markets in Mexico: "La Viga," the largest seafood market in Mexico City (in December 2010 and May 2015); and six markets in Quintana Roo State [one in Cancún (February 2011), one in Cozumel (January 2011), and four in Chetumal (January 2011 and February 2015)].

All the samples were fixed with $96 \%$ ethanol and immediately placed in ice.

Product details such as the commercial name, description of the goods (fillet, minced, or groundfish meat), and the scientific name (when the sample was obtained from the whole fish and identified in situ by employing standard taxonomic guides) were recorded. Almost all commercial products were photographed.

\section{DNA extraction, amplification, and sequencing}


108 A small piece $\left(1-3 \mathrm{~cm}^{3}\right)$ of muscle from the inside of each fresh sample was

109 extracted and washed with alcohol to prevent contamination. A total of 134

110 samples were then sub-sampled (approx. $1 \mathrm{~mm}^{3}$ tissue size), each of which was

111 placed in a well of an Eppendorf plate with a drop of 96\% ethanol for preservation

112 until DNA extraction.

113 DNA was extracted employing the glass fiber protocol described by Ivanova and

114 Hebert (2006). The first 652 bp of the COI gene (barcode) were amplified by

115 polymerase chain reaction (PCR) using the protocol and primers described by

116 Ivanova and Grainger (2007).

117 The polymerase chain reaction (PCR) reagents used were as follows: $12.5 \mu \mathrm{L}$ of

118 PCR reaction mix included $6.25 \mu \mathrm{L}$ of $10 \%$ trehalose, $2 \mu \mathrm{L}$ of distilled deionized 119 water and $1.25 \mu \mathrm{L}$ of $10 \times$ PCR buffer for the enzyme Taq Platinum, $0.625 \mu \mathrm{L}$ of

$120 \mathrm{MgCl}_{2}(50 \mathrm{mM}), 0.125 \mu \mathrm{L}$ of each primer $(0.01 \mathrm{mM}), 0.0625 \mu \mathrm{L}(10 \mathrm{mM}) \mathrm{dNTP}$ mix,

$1210.06 \mu \mathrm{L}$ Platinum Taq polymerase $(5 \mathrm{U} / \mu \mathrm{L})$, and $2.0 \mu \mathrm{L}$ of template DNA. The

122 thermocycler program used for amplification was as follows: DNA denaturation at

$12394^{\circ} \mathrm{C}$ for $1 \mathrm{~min}$, followed by 35 cycles of denaturation at $94^{\circ} \mathrm{C}$ for $30 \mathrm{~s}$, annealing at

$12452^{\circ} \mathrm{C}$ for $30 \mathrm{~s}$, elongation at $72^{\circ} \mathrm{C}$ for $1 \mathrm{~min}$, and a final extension at $72^{\circ} \mathrm{C}$ for 10

125 min. The PCR products were visualized on agarose gels (E-Gel囚, Invitrogen ${ }^{\mathrm{TM}}$ )

126 and analyzed with E-Editor TM 2.0 software.

127 The sequencing was carried out by the Canadian Centre for DNA Barcoding and

128 the Institute of Biology at the National Autonomous University of Mexico (UNAM).

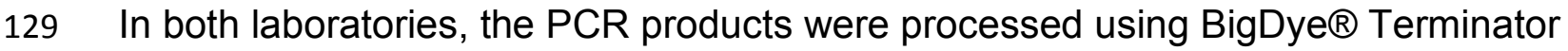

130 v.3.1. Purification of the PCR products was performed using Sephadex ${ }^{R}$ G-50 in a 
131 MultiScreen® Column, and the sequences were obtained using a 3730xI DNA

132 analyzer (Applied Biosystems). The sequences were edited and aligned using the

133 Codon Code v. 5.0.1 program.

Data analysis

136 Sequences were compared with previously published sequences that reached the 137 standard to get a Barcode Index Number (Ratnasingham and Hebert 2013), using 138 specimen identification tool provided in the Barcode of Life Data System (BOLD) 139 (Ratnasingham and Hebert 2007).. The criteria for sequence identification to the 140 species level were similarity values $\geq 99 \%$ and within the same BIN. Specimens 141 with values $<99 \%$ to $95 \%$ were assigned to genus, family, and order following the 142 same criteria as Valdez-Moreno et al. (2012), whereas those with values $<95 \%$, 143 were just assigned to a class level.

144 Neighbor-Joining (NJ) trees (Saitou and Nei 1987) were constructed using pairwise 145 genetic distances based on the Kimura two-parameter model (K2P) (Kimura 1980) 146 and pairwise deletion of missing data using MEGA 3 software (Kumar et al. 2004).

147 Specimen images, collection, and molecular data can be viewed at the

148 Boldsystems web site (www.boldsystems.org) within the Fish Market (FMK)

149 project. The sequences have also been deposited in GenBank (Accession

150 Numbers: MG837880-MG838002). 
153 We evaluated the percentage of mislabeling by comparing the commercial name of

154 the samples with the identification of the products using BOLD tools. The sample

155 was declared mislabeled if the species name determined through molecular

156 identification was not the same as that on the label in the market. Finally, we

157 consulted the IUNC list (http://www.iucnredlist.org) to determine the conservation

158 status of each of the identified species. All common names are in accordance with

159 those published by Page et al. (2013).

\section{Results and Discussion}

162 From the 134 samples collected, we obtained 129 sequences, representing a $96 \%$

163 success rate. This value is comparable with or even higher than that obtained in

164 other studies of this type (Ward et al. 2005; Richardson et al. 2007; Valdez-Moreno

165 et al. 2010; Xiong et al. 2016). The sequence lengths ranged from 586 to 652 base

166 pairs (bp), all of which were of high quality without insertions, deletions, or stop

167 codons.

168 Of the 129 sequences, 128 matched sequences in the BOLD reference library with 169 similarity values $\geq 99 \%$. One sequence showed a $94 \%$ similarity, and was identified 170 as belonging to the class Actinopterygii.

171 On the basis of these results, 47 clusters had a BIN assignment, from these, 44

172 had species assignment, with 38 genera, and 28 families (Fig.S1 and Table 1) 1 .

\footnotetext{
${ }^{1}$ Fig. S1. Full neighbor-joining tree based on genetic distances (K2P) from the COI gene, with their respective species names, sample IDs and BIN numbers.
} 
173 Three specimens could not be identified, these cases will be explained later.

174 Fourteen specimens belong to the group of sharks and rays (class

175 Elasmobranchii), and 33 belong to the group of bony fishes (class Actinopterygii).

176 The families represented by the largest number of species were the

177 Carcharhinidae (six), Serranidae (six), and Carangidae (four). The remainder of the 178 families was represented by one or two species.

179 All the species included in the ID tree grouped in single clusters that are non180 overlapping with other species cluster and show relatively high interspecific 181 divergences in BOLD, even between the most closely related species (Fig. S1)

182 These results allowed us to make highly reliable species assignments (Hanner et 183 al. 2011; Costa et al. 2012; Bénard-Capelle et al. 2015b)

184 For most species, the designated BIN was associated with a single specific name.

185 In nine cases, however, a single BIN was associated with multiple names:

186 Rhizoprionodon terraenovae, Hyporthodus nigritus, Caranx latus, Carcharhinus

187 brevipinna, Carcharhinus limbatus, Carcharhinus falciformes, Merluccius

188 productus, Thunnus sp., and Oreochromis sp. This problem occurs when species 189 are closely related, and therefore the genetic distance between them is very small 190 (Ward et al. 2005; Anbarasi et al. 2015).

191 However, for the first seven of these species, we could assign a scientific name 192 because we had identified the specimens in situ using identification guides, and 193 these designations were posteriorly corroborated by identification with the BOLD ID 194 tools.(see some photos at 
195

196

197

http://www.boldsystems.org/index.php/MAS_Management_Recordlist). Of the remaining two species, Thunnus sp., with the BIN: AAA7352, was associated with nine species, whereas Oreochromis sp., with the BIN: AAA8511, was associated with at least six species. In these two cases we were unable to assign a species name as we did not have any complete specimens. One more case had not any name associated, so it was left as Actinopterygii (BIN: ACV0720).

On the basis of an analysis of the 134 original samples, 81 were identified as bony fishes, 40 were sharks, and eight rays (Table 1). The most represented bony fishes were the greater amberjack or medregal (Seriola dumerili), striped catfish, panga, or Basa (Pangasianodon hypophthalmus), and king mackerel, sierra or carito (Scomberomorus cavalla) with 10 , seven, and six specimens, respectively. It is of interest to note that one of the most commonly sold fillets (Pangasianodon hypophthalmus) is not a Mexican species, but is of Asian origin and is imported here mainly from Vietnam.

In the case of sharks and related species, the silky shark or tiburon piloto (Carcharhinus falciformis), spinner shark or tiburon curro (Carcharhinus brevipinna), and southern stingray or raya latigo americana (Hypanus americanus) were represented by 10 , seven, and six specimens, respectively (Table 1). The first two are the most commonly caught shark species in the Gulf of Mexico and the Caribbean Sea, and they are among the 10 species most captured in the whole country, with $C$. brevipinna being the fifth most commonly reported in catches (SAGARPA 2014). The states where this species is most frequently captured are all on the Gulf of Mexico coast (Tamaulipas, Veracruz, Campeche, Tabasco, and 
218 Yucatan) (SAGARPA 2014). Due to the high demand for fish fillets in Mexico, in

219 the last 14 years, manta rays and rays have become important trade products. The

220 most important families with commercial importance are Myliobatidae,

221 Rhinopteridae, Rajidae, and Dasyatidae (SAGARPA 2007). H. americanus

222 belonging the family Dasyatidae, ranks as the third most commercially caught

223 species in the Atlantic Ocean (SAGARPA 2014).

224 The results of our analysis of the labels of the 129 sequenced samples indicates

225 that $106(82 \%)$ were labeled correctly, whereas the remaining $23(18 \%)$ were

226 mislabeled. This mislabeling rate is lower in comparison with the substitution rates

227 previously reported in other countries, which range from $19 \%$ to $50 \%$ (Wong and

228 Hanner 2008; Filonzi et al. 2010; Von Der Heyden et al. 2010; Hanner et al. 2011,

229 Series 2011; Cawthorn et al. 2012). An exception, however, is a study from France

230 that reports a substitution rate of only 3.7\% (Bénard-Capelle et al. 2015b).

231 The most substituted species was the sea catfish or flounder for basa $(P$.

232 hypophthalmus). Among other species, the southern stingray (H. americanus) and

233 giant electric ray (Narcine entemedor) were sold as cazon (small shark) or shark

234 (adult shark); silver carp (Hypophthalmichthys molitrix) was sold as red snapper

235 (Lutjanus campechanus) or cazon (common name); yellow-edge grouper

236 (Hyporthodus flavolimbatus) was sold as a ray (common name); the spinner shark 
237 (Carcharhinus brevipinna) was sold as a horse eye jack (Caranxlatus); and the

238 blacktip shark (Carcharhinus limbatus ) was labeled as blue marlin (Makaira 239 nigricans) (Fig.1, Table 1$)^{2}$.

240 Obviously, mislabeling has a direct effect on the price of a fillet-in most cases, we 241 found that the price was more than double that of the authorized price for the 242 correct product (Table 2). This mislabeling practice is common among traders 243 around the world. Ironically, however, we came across one case in which a species 244 with high economic value, the yellow-edge grouper ( $H$. flavolimbatus), fillets of 245 which have a trade price of MX\$120-180.00/kg (US\$6.70-10.00), was sold as a 246 low-cost species, a ray $(\mathrm{MX} \$ 40.00 / \mathrm{kg}$; US\$2.10). However, this case could 247 possibly be explained by the fact that the quality of the meat was no longer optimal, 248 and thus it was sold at a lower price, or perhaps simply the seller made an error 249 when labeling the product.

250 Interesting cases are the fillets of the so-called cazon. In Mexico, this word is a 251 common name that can be assigned to any shark up to $2 \mathrm{~m}$ in length, with a 252 cylindrical body, five-gill openings, two dorsal fins, and sharp teeth. Its meat is 253 white, soft, and somewhat dry (RAE 2017). Due to these characteristics, it is 254 appreciated in the market and can reach higher prices (sometimes more than 255 double) than those for larger sharks, as it forms part of many traditional foods in 256 coastal states of the country. Consequently, many species are sold under this 257 name (Fig. 1), although we also noticed the sale of a large number of small-sized

\footnotetext{
${ }^{2}$ Fig. 1. Price comparison between products labeled vs. barcode identification
} 
258

259

260

261

262

263

264

265

266

267

268

269

270

271

272

273

274

275

276

277

278

279

280

sharks. These results are consistent with those reported by the National Fisheries Institute (INAPESCA). Approximately $50 \%$ of the shark production associated with artisanal and river fisheries from the Gulf of Mexico are represented by newborn and juvenile organisms (SAGARPA 2007). These groups of organisms have slow growth, low reproductive potential, late sexual maturity, a long gestation period, and a small number of offspring (Castro 1993), and accordingly the stock populations of adults can be severely affected, leading to the possible local extirpation of some species (as for some of the species reported here).

Mexican legislation on seafood labeling focuses mainly on the dates of production and expiration of the product and provides some recommendations for its maintenance. It is evident, however, that our current legislation is incomplete, and there is little that specifically addresses the problems of illegal fishing and mislabelling or fraud when the product is on sale. Accordingly, it is necessary that our authorities undertake a thorough review and renewal of this legislation, which includes new requirements for the labeling of seafood. A good example in this regard is the Organization of the Markets in Fishery and Aquaculture Products Regulation (COM) in the European Union, published in 2013 as a renewal plan of the Common Fisheries Policy (Reg. (EU) n. 1379/2013, Cape IV). In this document, the Europeans introduced new mandatory requirements for fisheries and aquaculture products, including Commercial designation, Scientific Name, Production Method, Catch area/country, Body of water/country of production, and Fishing gear used (Jacquet and Pauly 2008; D'Amico et al. 2016). Special attention is devoted to label information, which should include the trade name and the 
281 scientific name, which is even more necessary for filleted products, where the loss

282 of morphological characteristics makes it difficult (if not impossible) to identify the 283 species (D’Amico et al. 2016).

284 The aim of such legislation is to establish minimum standards to ensure the 285 credibility of the certifications and uniformity in the labeling of the fish products 286 (Jacquet and Pauly 2008), thereby providing complete information for their 287 identification. This will provide consumers with an the opportunity to choose which 288 items to puchase and which ones to avoid, and thus prevent fraudulent practice 289 and illegal fishing (D'Amico et al. 2016).

290 Among different institutions there is already discussion regarding the 291 implementation of "Ecolabelling" in the sale of products. This new labeling 292 procedure is a voluntary method of environmental performance certification that is 293 practised around the world (Jacquet and Pauly 2007; Cawthorn et al. 2012; Reid et 294 al. 2013; FAO 2014, 2016; Lamendin et al. 2015). An ecolabel identifies products 295 or services proven environmentally preferable overall, within a specific product or 296 service category (https://globalecolabelling.net/what-is-eco-labelling/). This is 297 important because the consumers prefer to purchase and pay more for wild 298 products (Polymeros et al. 2015).

299 A further problem is that although there are some rules in place that regulate the 300 labeling of seafood products in Mexico, there is currently no capacity for the 301 supervision and regulation of the places where these products are sold, particularly 302 in local markets. In this regard, our review of the conservation status of all the 
303

304

305

306

307

308

309

310

311

312

313

314

315

316

317

318

319

320

321

322

323

324 325 (Ribotcarballal et al. 2005).

species we identified based on the IUCN list (http://www.iucnredlist.org) indicated that almost all the sharks we identified are near threatened.

Among the entire dataset, we found four species, the blue marlin (Makaira nigricans), hogfish (L. maximus), yellow-edge grouper (H. flavolimbatus), and shortfin mako (Isurus oxyrinchus), that are vulnerable (http://www.iucnredlist.org). Marlins are important not only as a food source but also as game species. In the Caribbean, marlin populations are diminishing, mainly in the Istiophoridae, and particularly M. nigricans (Valdez-Moreno et al. 2010). Indeed, in many fish tournaments, captured marlins are now routinely released, although the survival of these specimens remains uncertain as they are typically subjected to prolonged exhaustion and shock after being hooked. The hogfish or boquinete and the yellow-edge grouper or mero extraviado are economically valuable species with distributions in the Gulf of Mexico and the Caribbean Sea (McBride and Murphy 2003, Seyoum et al. 2015). Both species are highly appreciated in the southeast of Mexico. The Yucatan State has the highest catch of boquinete (Rodriguez-Gil 2009), whereas the mero extraviado is an important component of flake fishing and constitutes between $70 \%$ and $80 \%$ of the catch in this area (SAGARPA 2015). In spite of this, few studies been undertaken to analyze the fishery, and there is no specific close season for these species (Cass-Calay, S.L., and Bahnick, M 2002; Cook and Lombardi-Carlson 2007; Rodriguez-Gil 2009). The shortfin mako is a species with slow growth and maturation, which makes it highly susceptible to overfishing, and this shark is accordingly classified as a vulnerable species 
326

327

328

329

330

331

332

333

334

Among the other threatened species, the golden tilefish (Lopholatilus

chamaeleonticeps) and scalloped hammerhead (Sphyrna lewini) are currently

listed as endangered, whereas the Warsaw grouper (Hyporthodus nigritus) is

considered critically endangered (IUCN 2017). Of the remaining species identified in this study, $98 \%$ are registered in the red list, of which the $46 \%$ are considered to be of least concern status, whereas for four species (three rays and one shark) there is insufficient information available to assess their current status (Table 2).

In Mexico, although there are rules in place to regulate fisheries, there is currently no capacity for the supervision and regulation of the places where these products are sold. The data obtained in the present study can be used to inform the concerned authorities as to the value of DNA barcoding as a proven technique for determining which species are being traded in the Mexican markets. Currently, it is possible to obtain short sequences or mini-barcodes that facilitate taxa identification with $90 \%$ confidence in just minutes and at a comparatively low cost, as demonstrated with different species from Calakmul reserve (Ivanova et al. 2009). We believe that it is critically important to make the authorities aware of the potential of these new tools.

Finally, we hope that this work will provide an opportunity to initiate new projects on vulnerable species, to develop government programs for sustainable use of marine resources by providing better control for all fisheries to avoid overfishing, and to instigate better control over Mexican customs; for example, determining the precise identity of the shark fins or sea cucumber that are exported in high quantities to the Asian markets. 
349 Funding source

350 This study received support from the Mexican Barcode of Life (MEXBOL) network,

351 which provided funds through grants 194045 and 194025 by CONACyT. The

352 Chetumal node from this network assisted in processing the samples.

\section{Acknowledgments}

355 We thank our Mexican team, Jose Angel Cohuo and Miguel Valadez, from the

356 Instituto Tecnológico de Chetumal, for assistance in collection and sampling

357 processing, and Thomas McElwaine, for a review of the language used in this 358 paper. 
372

373

374

375

376

377

378

379

380

381

382

383

384

385

386

387

388

389

390

391

392

393

\section{References}

Anbarasi, G., Vignesh, R., Arulmoorthy, M.P., Rathiesh, A.C., and Srinivasan, M. 2015. Barcoding Profiling and Intra Species Variation Within the Barcode Region of Two Estuarine Fishes Oreochromis Mossambicus and Oreochromis Niloticus. 4(1): 59-68.

Ardura, A., Linde, A.R., Moreira, J.C., and Garcia-Vazquez, E. 2010. DNA barcoding for conservation and management of Amazonian commercial fish. Biol. Conserv. 143(6): 1438-1443. doi:10.1016/j.biocon.2010.03.019.

Ardura, A., Planes, S., and Garcia-Vazquez, E. 2011. Beyond Biodiversity: Fish Metagenomes. PLoS One 6(8): e22592. doi:10.1371/journal.pone.0022592.

Bartlett, S.E., and Davidson, W.S. 1992, March. Erratum: FINS (Forensically Informative Nucleotide Sequencing): A procedure for identifying the animal origin of biological specimens.

Bénard-Capelle, J., Guillonneau, V., Nouvian, C., Fournier, N., Le Loët, K., and Dettai, A. 2015a. Fish mislabelling in France: substitution rates and retail types. PeerJ 2(April): e714. doi:10.7717/peerj.714.

Bénard-Capelle, J., Guillonneau, V., Nouvian, C., Fournier, N., Le Loët, K., and Dettai, A. 2015b. Fish mislabelling in France: substitution rates and retail types. PeerJ 2(April): e714. doi:10.7717/peerj.714.

Carvalho, D.C., Palhares, R.M., Drummond, M.G., and Frigo, T.B. 2015a. DNA Barcoding identification of commercialized seafood in South Brazil: A governmental regulatory forensic program. Food Control 50(February 2016): 
395

396

397

398

399

400

401

402

403

404

405

406

407

408

409

410

411

412

413

414

415

Carvalho, D.C., Palhares, R.M., Drummond, M.G., and Frigo, T.B. 2015b. DNA Barcoding identification of commercialized seafood in South Brazil: A governmental regulatory forensic program. Food Control 50: 784-788. doi:10.1016/j.foodcont.2014.10.025.

Cass-Calay, S.L., and Bahnick, M 2002. Status of the Yellowedge Grouper Fishery in the Gulf of Mexico: Assessment 1.0. Govt Reports Announc. Index (GRA\&I), Issue 18, 2011 (18).

Castro, J.I. 1993. The shark nursery of Bulls Bay, South Carolina, with a review of the shark nurseries of the southeastern coast of the United States. Environ. Biol. Fishes 38(1-3): 37-48. doi:10.1007/BF00842902.

Cawthorn, D.M., Duncan, J., Kastern, C., Francis, J., and Hoffman, L.C. 2015. Fish species substitution and misnaming in South Africa: An economic, safety and sustainability conundrum revisited. Food Chem. 185: 165-181. doi:10.1016/j.foodchem.2015.03.113.

Cawthorn, D.M., Steinman, H.A., and Witthuhn, R.C. 2012. DNA barcoding reveals a high incidence of fish species misrepresentation and substitution on the South African market. Food Res. Int. 46(1): 30-40. doi:10.1016/j.foodres.2011.11.011.

Chang, S.-C., Kung, H.-F., Chen, H.-C., Lin, C.-S., and Tsai, Y.-H. 2008. Determination of histamine and bacterial isolation in swordfish fillets (Xiphias gladius) implicated in a food borne poisoning. Food Control 19(1): 16-21. 
doi:10.1016/j.foodcont.2007.01.005.

417 CONAPESCA. 2013. La pesca y acuacultura en cifras.

418 Cook, M., and Lombardi-Carlson, L. 2007. Yellowedge grouper (Epinephelus

419

420

421

422

423

424

425

426

427

428

429

430

431

432

433

434

435

436

437

flavolimbatus) and golden tilefish (Lopholatilus chamaeleonticeps)

distributions, habitat preferences and available biological samples. In NOAA Fisheries Service. Panama City.

Costa, F.O., Landi, M., Martins, R., Costa, M.H., Costa, M.E., Carneiro, M., Alves, M.J., Steinke, D., and Carvalho, G.R. 2012. A Ranking System for Reference Libraries of DNA Barcodes: Application to Marine Fish Species from Portugal. PLoS One 7(4): e35858. doi:10.1371/journal.pone.0035858.

Cutarelli, A., Amoroso, M.G., De Roma, A., Girardi, S., Galiero, G., Guarino, A., and Corrado, F. 2014. Italian market fish species identification and commercial frauds revealing by DNA sequencing. Food Control 37: 46-50. doi:10.1016/j.foodcont.2013.08.009.

D’Amico, P., Armani, A., Gianfaldoni, D., and Guidi, A. 2016. New provisions for the labelling of fishery and aquaculture products: Difficulties in the implementation of Regulation (EU) n. 1379/2013. Mar. Policy 71: 147-156. doi:10.1016/j.marpol.2016.05.026.

FAO. 1997. El estado mundial de la pesca y la acuicultura. Roma. Available from http://orton.catie.ac.cr/cgibin/wxis.exe/?IsisScript=CIDAB .xis\&amp;method=post\&amp;formato=2\&amp; cantidad=1\&amp; expresion=mfn=006500. 
438

439

440

441

442

443

444

445

446

447

448

449

450

451

452

453

454

455

456

457

458

459

FAO. 2014. The state of world fisheries and aquaculture. In Food and Agriculture Oraganization of the United Nations. doi:92-5-105177-1.

FAO. 2016. El estado mundial de la pesca y la acuicultura 2016. El estado mundial de la pesca y la acuicultura 2016. Contribución a la seguridad alimentaria y la nutrición para todos. Roma.

Filonzi, L., Chiesa, S., Vaghi, M., and Nonnis Marzano, F. 2010. Molecular barcoding reveals mislabelling of commercial fish products in Italy. Food Res. Int. 43(5): 1383-1388. doi:10.1016/j.foodres.2010.04.016.

Forbes, D., and Alexander, P. 2015. Breach with Intent: A Risk Analysis of Deliberate Security Breaches in the Seafood Supply Chain. In Global Supply Chain Security. Edited by A.R. Thomas and S. Vaduva. Springer New York, New York, NY. pp. 133-162. doi:10.1007/978-1-4939-2178-2.

Galal-Khallaf, A., Ardura, A., Borrell, Y.J., and Garcia-Vazquez, E. 2016. Towards more sustainable surimi? PCR-cloning approach for DNA barcoding reveals the use of species of low trophic level and aquaculture in Asian surimi. Food Control 61(2065): 62-69. doi:10.1016/j.foodcont.2015.09.027.

Hanner, R., Becker, S., Ivanova, N.V., and Steinke, D. 2011. FISH-BOL and Seafood Identification: Geographically Dispersed Case Studies Reveal Systemic Market Substitution Across Canada. Mitochondrial DNA 22(S1): 106-122. doi:10.3109/19401736.2011.588217.

Von Der Heyden, S., Barendse, J., Seebregts, A.J., and Matthee, C.A. 2010. Misleading the masses: Detection of mislabelled and substituted frozen fish 
460

461

462

463

464

465

466

467

468

469

470

471

472

473

474

475

476

477 Jacquet, J.L., and Pauly, D. 2008. Trade secrets: Renaming and mislabeling of

478

479

480

products in South Africa. ICES J. Mar. Sci. 67(1): 176-185.

doi:10.1093/icesjms/fsp222.

Huxley-Jones, E., Shaw, J.L.A., Fletcher, C., Parnell, J., and Watts, P.C. 2012.

Use of DNA barcoding to reveal species composition of convenience seafood. Conserv. Biol. 26(2): 367-71. doi:10.1111/j.1523-1739.2011.01813.x.

IUCN. 2017. The IUCN Red List of Threatened Species.

Ivanova, N.V., Borisenko, A.V., and Hebert, P.D.N. 2009. Express barcodes:

Racing from specimen to identification. Mol. Ecol. Resour. 9(Suppl. 1): 35-41. doi:10.1111/j.1755-0998.2009.02630.x.

Ivanova, N.V., Dewaard, J.R., and Hebert, P.D.N. 2006. An inexpensive, automation-friendly protocol for recovering high-quality DNA. Mol. Ecol. Notes 6(4): 998-1002. doi:10.1111/j.1471-8286.2006.01428.x.

Ivanova, N.V., and Grainger, C. 2007. CCDB Protocols: Sequencing. Appl. Biosyst. (1): $3-5$.

Jacquet, J.L., and Pauly, D. 2007. The rise of seafood awareness campaigns in an era of collapsing fisheries. Mar. Policy 31(3): 308-313.

doi:10.1016/j.marpol.2006.09.003. seafood. Mar. Policy 32(3): 309-318. doi:10.1016/j.marpol.2007.06.007.

Kimura, M. 1980. A simple method for estimating evolutionary rates of base substitutions through comparative studies of nucleotide sequences. J. Mol. 

Evol. 16(2): 111-120. doi:10.1007/BF01731581.

482

483 484 485 486 487 488 489 490 491 492 493 494 495 496 497 498 499 500 501 502

Kumar, S., Tamura, K., and Masatoshi, N. 2004. MEGA3: Integrated software for Molecular Evolutionary Genetics Analysis and sequence alignment. Brief. Bioinform. 5: 150-163.

Lamendin, R., Miller, K., and Ward, R.D. 2015. Labelling accuracy in Tasmanian seafood: An investigation using DNA barcoding. Food Control 47: 436-443. doi:10.1016/j.foodcont.2014.07.039.

Mackie, I., Pryde, S., Gonzales-Sotelo, C., Medina, I., Peréz-Martín, R., Quinteiro, J., Rey-Mendez, M., and Rehbein, H. 1999. Challenges in the identification of species of canned fish. Trends Food Sci. Technol. 10(1): 9-14. doi:10.1016/S0924-2244(99)00013-8.

McBride, R.S., and Murphy, M.D. 2003. Current and potential yield per recruit of Hogfish, Lachnolaimus maximus, in Florida. Gulf Caribb. Fish. Inst.

Ogden, R. 2008. Fisheries forensics: The use of DNA tools for improving compliance, traceability and enforcement in the fishing industry. Fish Fish. 9(4): 462-472. doi:10.1111/j.1467-2979.2008.00305.x.

Pappalardo, A.M., and Ferrito, V. 2015. DNA barcoding species identification unveils mislabeling of processed flatfish products in southern Italy markets. Fish. Res. 164: 153-158. Elsevier B.V. doi:10.1016/j.fishres.2014.11.004.

Pilger, T.J., Franssen, N.R., and Gido, K.B. 2008. Consumption of Native and Nonnative Fishes by Introduced Largemouth Bass (Micropterus salmoides) in the San Juan River, New Mexico. Southwest. Nat. 53(1): 105-108. 
504 Polymeros, K., Kaimakoudi, E., Schinaraki, M., Batzios, C., Nassivera, F., and

505 Sillani, S. 2015. Analysing consumers' perceived differences in wild and

506 farmed fish. Br. Food J. 117(3): 970-986. doi:10.1108/BFJ-12-2013-0362.

507 RAE. 2017. DLE: Lista de entradas - Diccionario de la lengua española - Edición 508 del Tricentenario.

509 Raimann, X., Rodríguez O.L., Chávez, P., and Torrejón, C. 2014. Mercury in fish

Ratnasingham, S., and Hebert, P.D.N. 2007. BARCODING, BOLD : The Barcode and its importance in health. Rev. Médica Chile 142(9): 1174-80. doi:10.4067/S0034-98872014000900012.

515

516 of Life Data System (www.barcodinglife.org). Mol. Ecol. Notes 7(April 2016): 355-364. doi:10.1111/j.1471-8286.2006.01678.x.

Ratnasingham, S., and Hebert, P.D.N. 2013. A DNA-Based Registry for All Animal Species: The Barcode Index Number (BIN) System. PLoS One 8(7). doi:10.1371/journal.pone.0066213.

Reid, G.M., Contreras Macbeath, T., and Csat??di, K. 2013. Global challenges in freshwater-fish conservation related to public aquariums and the aquarium industry. Int. Zoo Yearb. 47(1): 6-45. doi:10.1111/izy.12020.

Ribotcarballal, M., Galvanmagana, F., and Quinonezvelazquez, C. 2005. Age and growth of the shortfin mako shark, , from the western coast of Baja California Sur, Mexico. Fish. Res. doi:10.1016/j.fishres.2005.05.004. 
524 Richardson, D.E., Vanwye, J.D., Exum, A.M., Cowen, R.K., and Crawford, D.L.

525 2007. High-throughput species identification: from DNA isolation to

526 bioinformatics. Mol. Ecol. Notes 7(2): 199-207. doi:doi:10.1111/j.1471-

Robins, C.R., Bailey, R.M., Bond, C.E., Hooker, J.R., Lachner, E.A., Lea, R.N., and 8286.2006.01620.x.

531

532

533 Scott, W.B. 1991. Common and Scientific Names of Fishes from the United States and Canada. Fifth Edition. American Fisheries Society.

Rodriguez-Gil, L.A. 2009. La pesca de fomento del boquinete Lachnolaimus maximus en la costa del Estado de Yucatán, México. Proc. Gulf Caribb. Fish. Inst. 61: 218-229.

Rodríguez Sánchez, A., Peckham, H., Maldonado Díaz, D., and Hernández Cardoso, B. 2011. Esfuerzo ( CPUE ) en la pesca de escama de primera en Bahía de Ulloa, BCS ,. Loreto BCS.

Ropicki, A.J., Larkin, S.L., and Adams, C.M. 2010. Seafood Substitution and Mislabeling: WTP for a Locally Caught Grouper Labeling Program in Florida. Mar. Resour. Econ. 25(1): 77-93. doi:10.5950/0738-1360-25.1.77.

SAGARPA. 2007. NORMA Oficial Mexicana NOM-029-PESC-2006, Pesca responsable de tiburones y rayas. Especificaciones para su aprovechamiento. In Diario Oficial de la Federación.

SAGARPA. 2014. Periodos y zonas de veda de pesca de tiburón en el Golfo de México y Mar Caribe.

SAGARPA. 2015. Norma Oficial Mexicana 003-PESC-1993, para regular el 
aprovechamiento de las especies de sardina Monterrey, piña, crinuda, bocona, japonesa y de las especies anchoveta y macarela, con embarcaciones de cerco, en aguas de jurisdicción federal del océano. In Diario Oficial de la Federación. Mexico.

Saitou, N., and Nei, M. 1987. The neighbour-joining method: a new method for reconstructing phylogenetic trees. Mol. Biol. Evol. 4(4): 406-425. doi:citeulikearticle-id:93683.

Series, S. 2011. Fish Labelling Survey.

Seyoum, S., Collins, A.B., Puchulutegui, C., Mcbride, R.S., and Tringali, M.D. 2015. Genetically determined population structure of hogfish (Labridae: Lachnolaimus maximus) in the southeastern United States. Fish. Bull. 113: 442-455. doi:10.7755/FB.113.7.

Shen, Y., Kang, J., Chen, W., and He, S. 2016. DNA barcoding for the identification of common economic aquatic products in Central China and its application for the supervision of the market trade. Food Control 61: 79-91. doi:10.1016/j.foodcont.2015.08.038.

Steinke, Di., Bernard, A.M., Horn, R.L., Hilton, P., Hanner, R., and Shivji, M.S. 2017. DNA analysis of traded shark fins and mobulid gill plates reveals a high proportion of species of conservation concern. Sci. Rep. 7(1): 5-10. Springer US. doi:10.1038/s41598-017-10123-5.

Stevens, J.D., Bonfil, R., Dulvy, N.K., and Walker, P.A. 2000. The effects of fishing on sharks, rays, and chimaeras ( chondrichthyans ), and the implications for 

marine ecosystems. J. Mar. Sci. 57(3): 476-494. doi:10.1006/jmsc.2000.0724.

569 Todd, E.D. 2011. Procedures to Investigate Foodborne Illness. In Procedures to 570 Investigate Foodborne IIIness. doi:10.1007/978-1-4419-8396-1_1.

571 Tokeshi, M., Arakaki, S., and Daud, J.R.P. 2013. Consuming Diversity: Analysis of 572 Seasonal Catch Patterns in Multispecies Artisanal Reef Fisheries in North 573 Sulawesi, Eastern Indonesia 1. Pacific Sci. 67(1): 1-13. doi:10.2984/67.1.1.

574 Valdez-Moreno, M., Vásquez-Yeomans, L., Elías-Gutiérrez, M., Ivanova, N.V., and 575 Hebert, P.D.N. 2010a. Using DNA barcodes to connect adults and early life 576 stages of marine fishes from the Yucatan Peninsula, Mexico: potential in 577

Valdez-Moreno, M., Quintal-Lizama, C., Gómez-Lozano, R., and García-Rivas, M. 579

Wong, E.H.K., and Hanner, R.H. 2008. DNA barcoding detects market substitution

Ward, R.D., Zemlak, T.S., Innes, B.H., Last, P.R., and Hebert, P.D.N. 2005. DNA barcoding Australia's fish species. Philos. Trans. R. Soc. Lond. B. Biol. Sci. 360(1462): 1847-1857. doi:10.1098/rstb.2005.1716.

WWW.boldsystems.org, B.-S. (n.d.). www.boldsystems.org. 
589 Xiong, X., Guardone, L., Giusti, A., Castigliego, L., Gianfaldoni, D., Guidi, A., and

$590 \quad$ Armani, A. 2016. DNA barcoding reveals chaotic labeling and

591 misrepresentation of cod (Xue) products sold on the Chinese market. Food

592 Control 60: 519-532. doi:10.1016/j.foodcont.2015.08.028.

593

594

595

596

597

598

599

600

601

602

603

604

605

606

607

608

609 
Figure captions

611

612

Fig. 1. Comparison between the price of labeled products vs. barcode

613 identifications. The exchange rate at the time of collections was 1 US dollar $=18.00$ Mexican pesos.

614

615

\section{Supplementary material}

616

Fig. S1. Full neighbor-joining tree showing genetic distances (K2P)

617 based on a sequence of the $\mathrm{COI}$ gene, with respective species

618 names, sample IDs, and BIN numbers. 
Table1. List of fresh fillets sold in two Mexican markets identified by barcoding of bony fishes, sharks, and rays

** Market located in Mexico city, * Market located in Quintana Roo state, Bold letters indicate substituted species

\begin{tabular}{|c|c|c|c|c|c|c|c|}
\hline Sample ID & Label. (Spanish / English) & $\begin{array}{l}\text { Collection } \\
\text { Place }\end{array}$ & $\begin{array}{l}\text { Type of fish } \\
\text { product }\end{array}$ & $\begin{array}{l}\text { Similarity in } \\
\text { BOLD }(\%)\end{array}$ & Barcode Identification & Common name (Spanish/English) & Mislabeled \\
\hline MXV0001 & Sierra / King Mackerel & La Viga** & Fillet/Slice & 100 & Scomberomorus cavalla & Sierra y/o Carito / King Mackerel & No \\
\hline MXV0003 & Cazon / Small shark & La Viga** & Fillet / Hunk & 100 & Carcharhinus limbatus & Tiburón volador / Blacktip Shark & No \\
\hline MXV0004 & Sierra/ King Mackerel & La Viga** & Fillet/Slice & 100 & Scomberomorus cavalla & Sierra y/o Carito / King Mackerel & No \\
\hline MXV0006 & Pez español & La Viga** & Fillet & 100 & $\begin{array}{l}\text { Lopholatilus } \\
\text { chamaeleonticeps }\end{array}$ & Conejo amarillo / Golden tilefish & Yes \\
\hline MXV0008 & Pez español & La Viga** & Fillet & 100 & $\begin{array}{l}\text { Lopholatilus } \\
\text { chamaeleonticeps }\end{array}$ & Conejo amarillo / Golden tilefish & Yes \\
\hline MXV0009 & Cazon / Small shark & La Viga** & Fillet / Hunk & 100 & Mustelus sinusmexicanus & $\begin{array}{l}\text { Cazon del Golfo /Gulf Of Mexico } \\
\text { Smoothhound }\end{array}$ & No \\
\hline MXV0010 & Cazon / Small shark & La Viga** & Fillet / Hunk & 100 & Carcharhinus falciformes & Tiburón piloto / Silky Shark & No \\
\hline MXV0012 & Bragre / Gafftopsail Sea Catfish & La Viga** & Fillet & 100 & Bagre marinus & Bragre / Gafftopsail Sea Catfish & No \\
\hline MXV0013 & Papelillo / Atlantic lookdown & La Viga** & Fillet & 100 & Selene vomer & Papelillo / Atlantic lookdown & No \\
\hline MXV0014 & Medregal / Greater amberjack & La Viga** & Fillet / Slice & 100 & Seriola dumerili & Medregal / Greater amberjack & No \\
\hline MXV0015 & Medregal / Greater amberjack & La Viga** & Fillet / Slice & 100 & Seriola dumerili & Medregal / Greater amberjack & No \\
\hline MXV0016 & Papelillo / Atlantic lookdown & La Viga** & Fillet & 100 & Selene vomer & Papelillo / Atlantic lookdown & No \\
\hline MXV0017 & Papelillo / Atlantic lookdown & La Viga** & Fillet & 100 & Selene vomer & Papelillo / Atlantic lookdown & No \\
\hline MXV0018 & Cazon / Small shark & La Viga** & Fillet / Hunk & 100 & Galeocerdo cuvier & Tintorera / Tiger Shark & No \\
\hline MXV0024 & Mero / Grouper & La Viga** & Fillet & 100 & Mycteroperca microlepis & Abadejo, Mero / Gag, Grouper & No \\
\hline MXV0026 & Medregal / Greater amberjack & La Viga** & Fillet / Slice & 100 & Seriola dumerili & Medregal / Greater amberjack & No \\
\hline MXV0027 & Lenguado / Southern Flounder & La Viga** & Fillet & 100 & Paralichthys lethostigma & Lenguado / Southern Flounder & No \\
\hline MXV0028 & Robalo / Barred grunt & La Viga** & Fillet & 100 & Conodon nobilis & Robalo / Barred grunt & No \\
\hline MXV0029 & Cazon / Small shark & La Viga** & Fillet / Hunk & 100 & Carcharhinus falciformis & Tiburón piloto / Silky Shark & No \\
\hline MXV0030 & Cazon / Small shark & La Viga** & Fillet / Hunk & 100 & Hypanus americanus & $\begin{array}{l}\text { Raya látigo americana / Southern } \\
\text { stingray }\end{array}$ & Yes \\
\hline MXV0031 & Lenguado / Southern Flounder & La Viga** & Fillet & 100 & Paralichthys lethostigma & Lenguado / Southern Flounder & No \\
\hline MXV0032 & Medregal / Greater amberjack & La Viga** & Fillet / Slice & 100 & Seriola dumerili & Medregal / Greater amberjack & No \\
\hline MXV0033 & Pez español & La Viga** & Fillet & 100 & Caulolatilus cyanops & Pez españo I / Blackline & No \\
\hline MXV0034 & Mero / Grouper & La Viga** & Fillet & 100 & Epinephelus morio & Mero / Red grouper & No \\
\hline MXV0035 & Lenguado / Gulf flounder & La Viga** & Fillet & 100 & Paralichthys albigutta & Lenguado / Gulf flounder & No \\
\hline MXV0036 & Sierra / King Mackerel & La Viga** & Fillet/Slice & 100 & Scomberomorus cavalla & Sierra y/o Carito / King Mackerel & No \\
\hline MXV0037 & Bragre / Gafftopsail Sea Catfish & La Viga** & Fillet & 100 & Bagre marinus & Bragre / Gafftopsail Sea Catfish & No \\
\hline
\end{tabular}




\begin{tabular}{|c|c|}
\hline MXV0038 & |Bragre / Gafftopsail Sea Catfish \\
\hline MXV0039 & Cazon / Small shark \\
\hline MXV0041 & Cazon / Small shark \\
\hline MXV0042 & Medregal / Greater amberjack \\
\hline MXV0043 & Sierra / King Mackerel \\
\hline MXV0044 & Cazon / Small shark \\
\hline MXV0045 & Salmon / Atlantic salmon \\
\hline MXV0046 & Mero / Grouper \\
\hline MXV0047 & Cazon / Small shark \\
\hline MXV0048 & Cazon / Small shark \\
\hline MXV0049 & Bragre / Gafftopsail Sea Catfish \\
\hline MXV0050 & Cazon / Small shark \\
\hline MXV0051 & Bragre / Gafftopsail Sea Catfish \\
\hline MXV0052 & Mero / Grouper \\
\hline MXV0053 & Cazon / Small shark \\
\hline MXV0055 & Cazon / Small shark \\
\hline MXV0057 & Medregal / Greater amberjack \\
\hline MXV0059 & Cazon / Small shark \\
\hline MXV0060 & Cazon / Small shark \\
\hline MXV0061 & Cazon / Small shark \\
\hline MXV0062 & Cazon / Small shark \\
\hline MXV0063 & Lenguado / Southern Flounder \\
\hline MXV0064 & Cazon / Small shark \\
\hline MXV0065 & Mero / Grouper \\
\hline MXV0066 & Cazon / Small shark \\
\hline MXV0067 & Cazon / Small shark \\
\hline MXV0068 & Medregal / Greater amberjack \\
\hline MXV0069 & Cazon / Small shark \\
\hline MXV0070 & Cazon / Small shark \\
\hline MXV0071 & Robalo / Barred grunt \\
\hline MXV0072 & Cazon / Small shark \\
\hline MXV0073 & Cazon / Small shark \\
\hline MXV0074 & Robalo / Barred grunt \\
\hline MXV0075 & Cazon / Small shark \\
\hline MXV0076 & Cazon / Small shark \\
\hline
\end{tabular}

\begin{tabular}{|c|c|c|}
\hline La Viga** & Fillet & 100 \\
\hline La Viga** & Fillet / Hunk & 100 \\
\hline La Viga** & Fillet / Hunk & 100 \\
\hline La Viga** & Fillet / Slice & 100 \\
\hline La Viga** & Fillet/Slice & 100 \\
\hline La Viga** & Fillet / Hunk & 100 \\
\hline La Viga** & Fillet & 100 \\
\hline La Viga** & Fillet & 100 \\
\hline La Viga** & Fillet / Hunk & 100 \\
\hline La Viga** & Fillet / Hunk & 100 \\
\hline La Viga** & Fillet & 100 \\
\hline La Viga** & Fillet / Hunk & 100 \\
\hline La Viga** & Fillet & 100 \\
\hline La Viga** & Fillet & 100 \\
\hline La Viga** & Fillet / Hunk & 100 \\
\hline La Viga** & Fillet / Hunk & 100 \\
\hline La Viga** & Fillet / Slice & 100 \\
\hline La Viga** & Fillet / Hunk & 100 \\
\hline La Viga** & Fillet / Hunk & 100 \\
\hline La Viga** & Fillet / Hunk & 100 \\
\hline La Viga** & Fillet / Hunk & 100 \\
\hline La Viga** & Fillet & 100 \\
\hline La Viga** & Fillet / Hunk & 100 \\
\hline La Viga** & Fillet & 100 \\
\hline La Viga** & Fillet / Hunk & 100 \\
\hline La Viga** & Fillet / Hunk & 100 \\
\hline La Viga** & Fillet / Slice & 100 \\
\hline La Viga** & Fillet / Hunk & 100 \\
\hline La Viga** & Fillet / Hunk & 100 \\
\hline La Viga** & Fillet & 100 \\
\hline La Viga** & Fillet / Hunk & 100 \\
\hline La Viga** & Fillet / Hunk & 100 \\
\hline La Viga** & Fillet & 100 \\
\hline La Viga** & Fillet / Hunk & 100 \\
\hline La Viga** & Fillet / Hunk & 100 \\
\hline
\end{tabular}

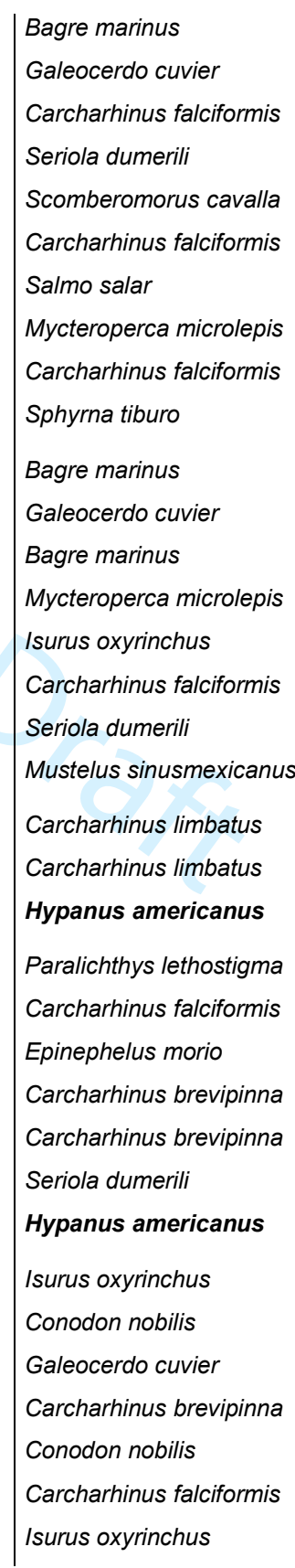

\begin{tabular}{|c|}
\hline Bragre / Gafftopsail Sea Catfish \\
\hline Tintorera / Tiger Shark \\
\hline Tiburón piloto / Silky Shark \\
\hline Medregal / Greater amberjack \\
\hline Sierra y/o Carito / King Mackerel \\
\hline Tiburón piloto / Silky Shark \\
\hline Salmon / Atlantic salmon \\
\hline Abadejo y/o Mero / Gag y/o Grouper \\
\hline Tiburón piloto / Silky Shark \\
\hline $\begin{array}{l}\text { Cornuda cabeza de pala /Bonnethead } \\
\text { Shark } \\
\text { Bragre / Gafftopsail Sea Catfish }\end{array}$ \\
\hline Tintorera / Tiger Shark \\
\hline Bragre / Gafftopsail Sea Catfish \\
\hline Abadejo y/o Mero / Gag y/o Grouper \\
\hline Mako / Shortfin Mako \\
\hline Tiburón piloto / Silky Shark \\
\hline Medregal / Greater amberjack \\
\hline $\begin{array}{l}\text { Cazon del Golfo /Gulf Of Mexico } \\
\text { Smoothhound } \\
\text { Tiburón volador / Blacktip Shark }\end{array}$ \\
\hline Tiburón volador / Blacktip Shark \\
\hline $\begin{array}{l}\text { Raya látigo americana / Southern } \\
\text { stingray } \\
\text { Lenguado / Southern Flounder }\end{array}$ \\
\hline Tiburón piloto / Silky Shark \\
\hline Mero / Red grouper \\
\hline Tiburón curro / Spinner Shark \\
\hline Tiburón curro / Spinner Shark \\
\hline Medregal / Greater amberjack \\
\hline $\begin{array}{l}\text { Raya látigo americana / Southern } \\
\text { stingray } \\
\text { Mako / Shortfin Mako }\end{array}$ \\
\hline Robalo / Barred grunt \\
\hline Tintorera / Tiger Shark \\
\hline Tiburón curro / Spinner Shark \\
\hline Robalo / Barred grunt \\
\hline Tiburón piloto / Silky Shark \\
\hline Mako / Shortfin Mako \\
\hline
\end{tabular}




\begin{tabular}{l|l} 
MXV0077 & Salmon / Atlantic salmon \\
MXV0078 & Sierra / King Mackerel \\
MXV0079 & Robalo / Barred grunt \\
MXV0080 & Medregal / Greater amberjack \\
MXV0081 & Bragre / Gafftopsail Sea Catfish \\
MXV0082 & Angel / Grey angelfish \\
MXV0083 & Mero / Grouper \\
MXV0084 & Bragre / Gafftopsail Sea Catfish \\
MXV0085 & Cazon / Small shark \\
MXV0087 & Bragre / Gafftopsail Sea Catfish \\
MXV0090 & Xcochin / Queen triggerfish \\
MXV0094 & Bacalao / Walleye pollock \\
MXV0325 & Barracuda / Great barracuda \\
MXV0326 & Barracuda / Great barracuda \\
MXV0327 & Palometa / Crevalle Jack \\
MXV0328 & Pargo / Red porgy \\
MXV0329 & Sierra / King Mackerel \\
MXV0330 & Medregal / Greater amberjack \\
MXV0331 & Medregal / Greater amberjack \\
MXVV71 & Boquinete / Hogfish \\
MXV0332 & Bopopa / Atlantic tripletail \\
MXV0335 & Bragre / Gafftopsail Sea Catfish \\
MXV0336 & Tilapia / Mozambique tilapia \\
MXV0337 & Abadejo / Gag \\
MXV0339 & Bragre / Gafftopsail Sea Catfish \\
MXV0344 & Corvina / Spotted seatrout \\
MXV0345 & Corvina / Spotted seatrout \\
MXV0346 & Bragre / Gafftopsail Sea Catfish \\
MXV583 & Mero / Grouper \\
MX65 & Boquinete / Hogfish \\
Actinopterygii \\
Limon / Blacknose Shark \\
Lucero / Spotted sand bass \\
MXV
\end{tabular}

\begin{tabular}{|c|c|c|}
\hline La Viga** & Fillet & 100 \\
\hline La Viga** & Fillet/Slice & 100 \\
\hline La Viga** & Fillet & 100 \\
\hline La Viga** & Fillet / Slice & 100 \\
\hline Cozumel * & Fillet & 100 \\
\hline Cozumel * & Fillet & 100 \\
\hline Cozumel * & Fillet & 100 \\
\hline Cozumel * & Fillet & 100 \\
\hline Cozumel * & Fillet / Hunk & 100 \\
\hline Cozumel * & Fillet & 100 \\
\hline Cozumel * & Fillet & 100 \\
\hline Cozumel * & Fillet & 100 \\
\hline Cancun* & Slice & 100 \\
\hline Cancun* & Slice & 100 \\
\hline Cancun* & Fillet & 100 \\
\hline Cancun* & Fillet / Slice & 100 \\
\hline Cancun* & Fillet/Slice & 100 \\
\hline Cancun* & Fillet / Slice & 100 \\
\hline Cancun* & Fillet / Slice & 100 \\
\hline Cancun* & Fillet & 100 \\
\hline Chetumal $^{*}$ & Fillet & 100 \\
\hline Chetumal ${ }^{*}$ & Fillet & 100 \\
\hline Chetumal $^{\star}$ & Fillet & 100 \\
\hline Chetumal $^{*}$ & Fillet & 100 \\
\hline Chetumal $^{*}$ & Fillet & 100 \\
\hline Chetumal $^{*}$ & Fillet & 100 \\
\hline Chetumal* $^{*}$ & Fillet & 100 \\
\hline Chetumal $^{*}$ & Fillet & 100 \\
\hline Cancun* & Fillet & 100 \\
\hline La Viga** & Fillet & 94 \\
\hline La Viga** & Fillet / Hunk & 100 \\
\hline La Viga** & Fillet & 100 \\
\hline La Viga** & Fillet & 100 \\
\hline La Viga** & Fillet / Hunk & 100 \\
\hline La Viga** & Fillet/Hunk & 100 \\
\hline
\end{tabular}

\begin{tabular}{|l} 
Salmo salar \\
Scomberomorus cavalla \\
Conodon nobilis \\
Seriola dumerili \\
Pangasianodon \\
hypophthalmus \\
Pomacanthus arcuatus \\
Epinephelus morio \\
Pangasianodon \\
hypophthalmus \\
Carcharhinus falciformis \\
Pangasianodon \\
hypophthalmus \\
Balistes vetula \\
Gadus chalcogrammus \\
Sphyraena barracuda \\
Sphyraena barracuda \\
Caranx hippos \\
Pagrus pagrus \\
Scomberomorus cavalla \\
Seriola dumerili \\
Seriola dumerili \\
Lachnolaimus maximus \\
Pangasianodon \\
hypophthalmus \\
Oreochromis sp. \\
Mycteroperca microlepis \\
Pangasianodon \\
hypophthalmus \\
Cynoscion nebulosus \\
Cynoscion nebulosus \\
Pangasianodon \\
hypophthalmus \\
Hyporthodus nigritus \\
Lachnolaimus maximus \\
Actinopterygii \\
Carcharhinus acronotus \\
Paralabrax maculatofasciatus \\
Lobotes surinamensis \\
\hline
\end{tabular}

\begin{tabular}{l|l} 
Salmon / Atlantic salmon & No \\
Sierra y/o Carito / King Mackerel & No \\
Robalo / Barred grunt & No \\
Medregal / Greater amberjack & No \\
Panga, Bassa / Striped catfish & Yes \\
Angel / Grey angelfish & No \\
Mero / Red grouper & No \\
Panga, Bassa / Striped catfish & Yes \\
Tiburón piloto / Silky Shark & No \\
Panga, Bassa / Striped catfish & Yes \\
Xcochin / Queen triggerfish & No \\
Bacalao / Walleye pollock & No \\
Barracuda / Great barracuda & No \\
Barracuda / Great barracuda & No \\
Palometa / Crevalle Jack & No \\
Pargo / Red porgy & No \\
Sierra y/o Carito / King Mackerel & No \\
Medregal / Greater amberjack & No \\
Medregal / Greater amberjack & No \\
Boquinete / Hogfish & No \\
Panga, Bassa / Striped catfish & Nos \\
Tilapia / Mozambique tilapia & No \\
Abadejo y/o Mero / Gag y/o Grouper & No \\
Panga, Bassa / Striped catfish & Yes \\
Corvina / Spotted seatrout & No \\
Corvina / Spotted seatrout & No \\
Panga, Bassa / Striped catfish & Yes \\
Mero / Warsaw grouper & No \\
Boquinete / Hogfish & No \\
unidentifiable & Tiburón cangüay / Limón \\
Lucero / Spotted sand bass & Nopana / Atlantic tripletail \\
Raya lamericana / Southern stingray & No \\
Atuna
\end{tabular}




\begin{tabular}{|c|c|c|c|c|c|c|c|}
\hline MXV674 & Chopa / Atlantic tripletail & | La Viga** & Fillet & 100 & Lobotes surinamensis & Chopa / Atlantic tripletail & | No \\
\hline MXV675 & Raya / Ray & La Viga** & Fillet / Hunk & 99 & Gymnura micrura & Raya cola de rata / Smooth Butterfly Ray & No \\
\hline MXV676 & Raya / Ray & La Viga** & Fillet / Hunk & 100 & Hypanus americanus & Raya látigo americana / Southern stingray & No \\
\hline MXV678 & Raton / Southern kingfish & La Viga** & Fillet & 99 & Menticirrhus americanus & Raton / Southern kingfish & No \\
\hline MXV679 & Cazon / Small shark & La Viga** & Fillet / Hunk & 99 & Rhizoprionodon terraenovae & Cazon de ley / Sharpnose Shark & No \\
\hline MXV680 & Cazon / Small shark & La Viga** & Fillet / Hunk & 100 & Carcharhinus brevipinna & Tiburón curro / Spinner Shark & No \\
\hline MXV681 & Caña & La Viga $a^{* *}$ & Fillet / Hunk & 100 & Mustelus canis & Cazón dientudo / Dusky Smoothhound & Yes \\
\hline MXV682 & Abadejo / Gag & La Viga** & Fillet & 100 & Mycteroperca microlepis & Abadejo y/o Mero / Gag y/o Grouper & No \\
\hline MXV683 & Cazon / Small shark & La Viga** & Fillet / Hunk & 100 & Carcharhinus brevipinna & Tiburón curro / Spinner Shark & No \\
\hline MXV684 & Cazon / Small shark & La Viga** & Fillet / Hunk & 100 & Carcharhinus falciformis & Tiburón piloto / Silky Shark & No \\
\hline MXV686 & Raya / Ray & La Viga ${ }^{* *}$ & Fillet & 100 & Hyporthodus flavolimbatus & Mero / Yellowedge grouper & Yes \\
\hline MXV687 & Tuburón martillo /Scalloped Hammerhead & La Viga** & Fillet / Hunk & 100 & Sphyrna lewini & Tuburón martillo /Scalloped Hammerhead & No \\
\hline MXV688 & Tuburón martillo /Scalloped Hammerhead & La Viga ${ }^{* *}$ & Fillet / Hunk & 100 & Sphyrna lewini & Tuburón martillo /Scalloped Hammerhead & No \\
\hline MXV689 & Cazon / Small shark & La Viga ${ }^{* *}$ & Fillet / Hunk & 100 & Carcharhinus acronotus & Tiburón cangüay / Limón & No \\
\hline MXV690 & Cazon / Small shark & La Viga ${ }^{* *}$ & Fillet / Hunk & 100 & Carcharhinus acronotus & Tiburón cangüay / Limón & No \\
\hline MXV691 & Cazon / Small shark & La Viga** & Fillet / Hunk & 100 & Carcharhinus acronotus & Tiburón cangüay / Limón & No \\
\hline MXV692 & Cazon / Small shark & La Viga ${ }^{* *}$ & Fillet / Hunk & 99 & Rhizoprionodon terraenovae & Cazon de ley / Sharpnose Shark & No \\
\hline MXV693 & Marlin / Blue marlin & La Viga* & Fillet / Hunk & 100 & Makaira nigricans & Marlin azul / Blue marlin & No \\
\hline MXV694 & Sierra / Mackerel & La Viga ${ }^{* *}$ & Grouthmeat & 99 & Merluccius productus & Merluza norteña / Pacific hake & Yes \\
\hline MXV695 & Cazon / Small shark & La Viga** & Fillet / Hunk & 100 & Carcharhinus brevipinna & Tiburón curro / Spinner Shark & No \\
\hline MXV696 & Huachinango / Red snapper & La Viga ${ }^{* *}$ & Fillet & 100 & Hypophthalmichthys molitrix & Carpa plateada / Silver carp & Yes \\
\hline MXV697 & Huachinango / Red snapper & La Viga** & Fillet & 100 & Hypophthalmichthys molitrix & Carpa plateada / Silver carp & Yes \\
\hline MXV698 & Tiburon / Shark & La Viga ${ }^{* *}$ & Fillet / Hunk & 100 & Narcine entemedor & Raya eléctrica gigante / Giant electric & Yes \\
\hline MXV699 & Huachinango / Red snapper & La Viga ${ }^{* *}$ & Fillet & 100 & Hypophthalmichthys molitrix & Carpa plateada / Silver carp & Yes \\
\hline MXV700 & Lenguado / Flounder & La Viga $a^{* *}$ & Fillet & 100 & $\begin{array}{l}\text { Pangasianodon } \\
\text { hypophthalmus }\end{array}$ & Panga, Bassa / Striped catfish & Yes \\
\hline MXV701 & $\begin{array}{l}\text { Tuburón martillo / Scalloped } \\
\text { Hammerhead }\end{array}$ & La Viga* & Fillet / Hunk & 100 & $\begin{array}{l}\text { nypopna lewini } \\
\text { Sphyrna }\end{array}$ & Tuburón martillo / Scalloped Hammerhead & No \\
\hline MXV703 & Gato / Cat-fish & La Viga ${ }^{* *}$ & Fillet / Hunk & 100 & Makaira nigricans & Marlin azul / Blue marlin & Yes \\
\hline MXV704 & Marlin / Blue marlin & La Viga ${ }^{* *}$ & Fillet / Hunk & 100 & Carcharhinus limbatus & Tiburón volador / Blacktip Shark & Yes \\
\hline MXV705 & Tiburon / Shark & La Viga ${ }^{* *}$ & Fillet / Hunk & 100 & Hypanus americanus & $\begin{array}{l}\text { Raya látigo americana / Southern } \\
\text { stingray }\end{array}$ & Yes \\
\hline MXV706 & Cazon / Small shark & La Viga** & Fillet & 100 & Hypophthalmichthys molitrix & Carpa plateada/ Silver carp & Yes \\
\hline MXV707 & Robalo / Snook fish & La Viga** & Fillet & 100 & Caranx latus & Jurel / Horse eye jack & Yes \\
\hline MXV709 & Jurel / Yellow jack & La Viga $a^{* *}$ & Fillet / Hunk & 100 & Carcharhinus brevipinna & Tiburón curro / Spinner Shark & Yes \\
\hline
\end{tabular}


Table 2. Threatened status of the species identified using a barcode database

\begin{tabular}{|c|c|c|c|}
\hline Barcode Identification & Bin number & Protection Status in Mexico & IUCN Red List Status \\
\hline Actinopterygii & BOLD:ACV0720 & None & Least concern \\
\hline Bagre marinus & BOLD:AAM3078 & None & Least concern \\
\hline Balistes vetula & BOLD:AAB6283 & None & Near threatened \\
\hline Caranx hippos & BOLD:AAB9930 & None & Least concern \\
\hline Caranx latus & BOLD:AAB0584 & None & Least concern \\
\hline Carcharhinus acronotus & BOLD:ABY4484 & Fixed temporary closure & Near threatened \\
\hline Carcharhinus brevipinna & BOLD:AAA3388 & Fixed temporary closure & Near threatened \\
\hline Carcharhinus falciformis & BOLD:AAA3387 & Fixed temporary closure & Near threatened \\
\hline Carcharhinus limbatus & BOLD:AAA5251 & Fixed temporary closure & Near threatened \\
\hline Caulolatilus cyanops & BOLD:AAU6310 & None & Least concern \\
\hline Conodon nobilis & |BOLD:AAM9279 & None & Least concern \\
\hline Cynoscion nebulosus & BOLD:AAI9478 & None & Least concern \\
\hline Epinephelus morio & BOLD:AAF1000 & Fixed temporary closure & Near threatened \\
\hline Gadus chalcogrammus & BOLD:AAA3069 & None & Unregistered \\
\hline Galeocerdo cuvier & BOLD:AAA2006 & Fixed temporary closure & Near threatened \\
\hline Gymnura micrura & BOLD:AAL3437 & Fixed temporary closure & Data deficient \\
\hline Hypanus americanus & BOLD:AAA5613 & Fixed temporary closure & Data deficient \\
\hline Hypophthalmichthys molitrix & BOLD:AAF6633 & None (Introduced) & Near threatened \\
\hline Hyporthodus flavolimbatus & BOLD:AAC5444 & Fixed temporary closure & Vulnerable \\
\hline Hyporthodus nigritus & BOLD:AAF0389 & Fixed temporary closure & Critically endangered \\
\hline Isurus oxyrinchus & BOLD:AAA4689 & Fixed temporary closure & Vulnerable \\
\hline Lachnolaimus maximus & BOLD:AAC3462 & None & Vulnerable \\
\hline Lobotes surinamensis & BOLD:AAC1878 & None & Least concern \\
\hline Lopholatilus chamaeleonticeps & BOLD:AAK6870 & None & Endangered \\
\hline Makaira nigricans & BOLD:ABZ5150 & Permanent closure & Vulnerable \\
\hline Menticirrhus americanus & BOLD:AAB5199 & None & Least concern \\
\hline Merluccius productus & BOLD:AAB5094 & None & Least concern \\
\hline Mustelus canis & BOLD:ABY7045 & Fixed temporary closure & Near threatened \\
\hline Mustelus sinusmexicanus & BOLD:AAB2974 & Fixed temporary closure & Data deficient \\
\hline Mycteroperca microlepis & BOLD:AAB9158 & Fixed temporary closure & Least concern \\
\hline Narcine entemedor & BOLD:AAN2285 & Fixed temporary closure & Data deficient \\
\hline Oreochromis sp. & BOLD:AAA8511 & None (Introduced) & \\
\hline Pagrus pagrus & BOLD:AAC8526 & None & Least concern \\
\hline Pangasianodon hypophthalmus & BOLD:AAE3237 & None (Imported) & Endangered \\
\hline Paralabrax maculatofasciatus & BOLD:AAK5063 & None & Least concern \\
\hline Paralichthys albigutta & BOLD:AAO1988 & None & Least concern \\
\hline Paralichthys lethostigma & BOLD:AAG2602 & None & Near threatened \\
\hline Pomacanthus arcuatus & BOLD:AAB6281 & None & Least concern \\
\hline Rhizoprionodon terraenovae & BOLD:AAB3213 & Fixed temporary closure & Near threatened \\
\hline Salmo salar & BOLD:AAA3435 & None & Least concern \\
\hline Scomberomorus cavalla & BOLD:AAA7856 & None & Least concern \\
\hline Selene vomer & BOLD:AAF1235 & None & Least concern \\
\hline Seriola dumerili & BOLD:AAB5912 & None & Least concern \\
\hline Sphyraena barracuda & BOLD:AAA6100 & None & Least concern \\
\hline Sphyrna lewini & BOLD:AAA2402 & Permanent closure & Endangered \\
\hline Sphyrna tiburo & BOLD:ADK7234 & Fixed temporary closure & Least concern \\
\hline Thunnus sp. & BOLD:AAA7352 & None & Least concern \\
\hline
\end{tabular}




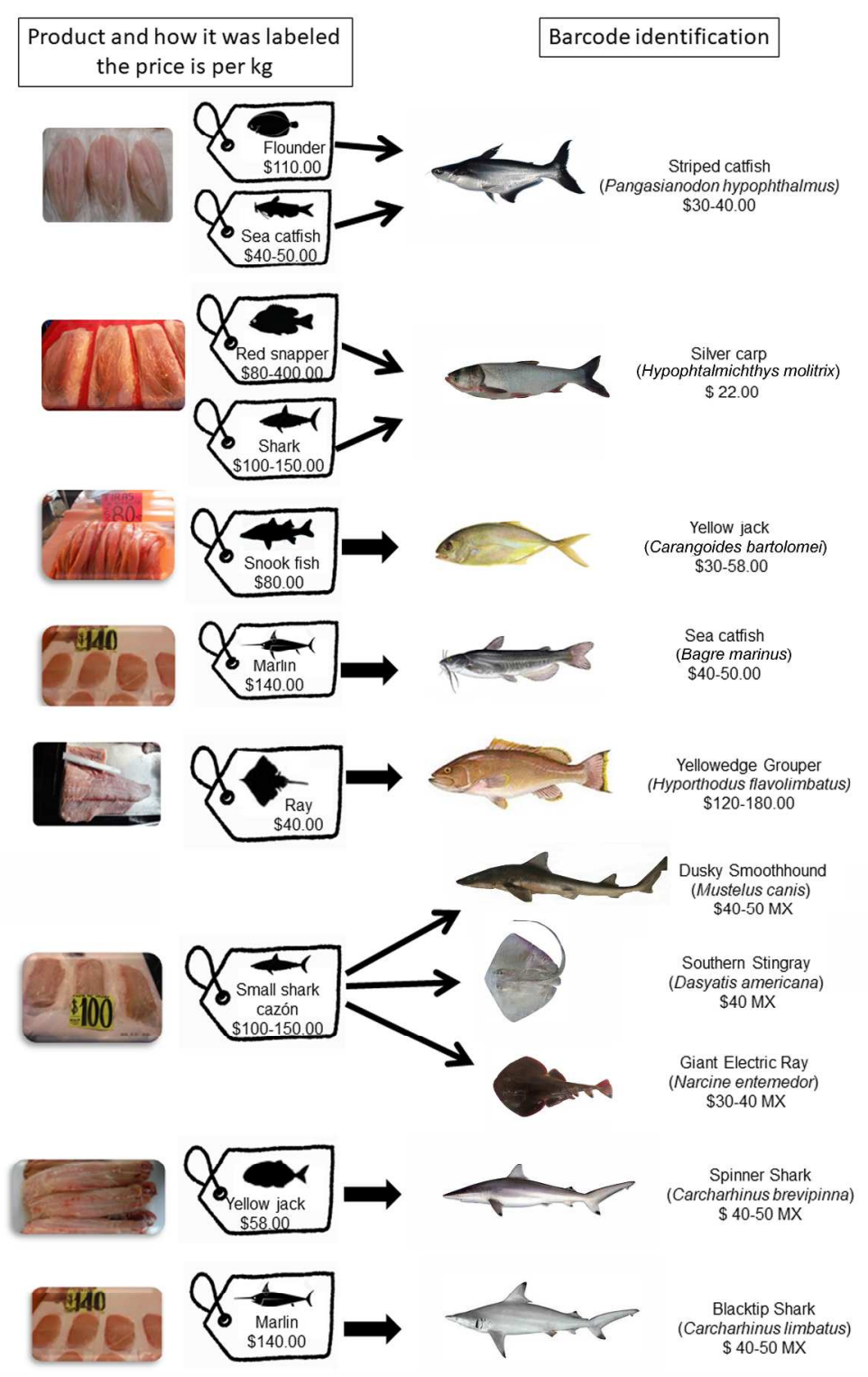

Fig. 1. Comparison between the price of labeled products vs. barcode identifications. The exchange rate at the time of collections was 1 US dollar $=18.00$ Mexican pesos.

$274 \times 351 \mathrm{~mm}(300 \times 300 \mathrm{DPI})$ 